\title{
Protein quality assessment of commercial whey protein supplements commonly consumed in Turkey by in vitro protein digestibility-corrected amino acid score (PDCAAS)
}

\author{
Halime PEHLIVANOĞLU ${ }^{1 *}$ (D), Hamide Feyza BARDAKÇI², Mustafa YAMAN²
}

\begin{abstract}
Whey protein is preferred in sports nutrition because of its rich essential amino acids and protein digestibility rate compared to other protein sources. The purpose of this study was to determine the amino acid content and in vitro protein digestibility of whey protein supplements and evaluate their protein quality using the in vitro protein digestibility-corrected amino acid score (PDCAAS) method. The amount of amino acids were determined using high performance liquid chromatography (HPLC) and the protein digestibility was determined by in vitro simulated gastrointestinal tract. A high levels of glycine and very low levels of cysteine were detected in some samples. The ratio of glycine in 4 out of 14 samples ranged between 7.4 and $40.3 \%$. The ratio of essential amino acids and branched chain amino acids in all samples were less than the reference protein. The in vitro protein digestibility of whey proteins ranged from 50.4 to $79.6 \%$, which was very low compared with the values indicated in the literature. The PDCAAS values of whey proteins were very low and ranged from 0.08 to 0.71 in the samples. Based on these results, manufacturers should revise their processing techniques in order to provide high quality whey protein.
\end{abstract}

Keywords: whey protein; amino acid; digestibility; quality; PDCAAS.

Practical Application: Protein quality assessment of commercial whey protein supplements by in vitro protein digestibilitycorrected amino acid score (PDCAAS).

\section{Introduction}

Athletes, bodybuilders, and physically active individuals extensively consume protein-rich products such as whey, soy, casein, and egg (Williams, 2005). Among these, whey and casein are the preferred proteins in terms of quality (Tipton et al., 2004). Whey and casein are mostly derived from cow milk. Cow milk protein consists of $80 \%$ casein and $20 \%$ whey protein. Whey protein is consisted of $\beta$-lactoglobulin ( $\beta$-LG) and $\alpha$-lactoglobulin ( $\alpha$-LG) and a small amount of immunoglobulin (Bobe et al., 1998). $\beta$-LG has 162 amino acids and the most distinctive feature of whey protein compared to casein is that it has 5 cysteines in its structure (Sava et al., 2005). This significant difference is used to determine the quality difference between casein and whey protein (European Union, 1990; Ballin, 2006).

Whey protein is commercially produced from cheese whey. Cheese whey is the liquid resulting from the separation of caseins and milk fat during the cheesemaking process (Alves et al., 2019). The quality and nutritional composition of whey depends on the cheese making processes, the type of milk used, environmental conditions and animals. The use of cheese whey is of industrial interest, due to the large amount produced, and availability of nutrients such as lactose, soluble proteins, lactic acid and B vitamins (Fangmeier et al., 2019). Therefore, cheese whey can be used in the formulation of whey dairy beverages, ricotta, whey concentrate and milk blends (Guimarães et al., 2018, 2019; Trindade et al., 2019). Whey protein is especially preferred in sports nutrition because of its rich essential amino acid (EAA) content and protein quality compared to other protein sources
(Rankin \& Darragh, 2006). In addition, the amount of branched chain amino acids (BCAAs) (leucine, isoleucine, and valine) in the structure of whey protein is higher than other protein sources (Pennings et al., 2011; Khanam et al., 2013). Unlike other amino acids, BCAAs are not metabolized in the liver and are used directly by skeletal muscle. These BCAAs serve as an effective source of energy for the muscles during exercise as well as a ready source for the synthesis of muscle proteins (Shimomura et al., 2004; Nicastro et al., 2012). Among the BCAAs, leucine also functions as a critical regulator of translation initiation in muscle protein synthesis. Whey protein contains a higher amount of leucine than casein (Norton \& Layman, 2006). Another important feature of whey protein compared to other proteins is that it is easier to digest and absorb in the body. Therefore, it is a good source to address immediate protein requirements after exercise or physical activity (Tang et al., 2009). Whey protein is available as hydrolysate, isolate, and concentrate (Lucena et al., 2007). Whey protein hydrolysate is a type of protein separated into its own amino acids, although the price is higher than other proteins because the production method is more costly (Pouliot et al., 1999).

The quality of the protein in a food is evaluated by the rate of digestion in the small intestine (Dangin et al., 2001). Protein digestibility is an important factor when determining the amount of protein absorbed in the small intestine after digestion and reflects the effectiveness of the protein's use in the diet (World Health Organization, 2007). The data regarding the digestibility of proteins 
are limited due to ethical restrictions. Therefore, a simulated in vitro protein digestibility model is a widely used method for determining protein digestibility. The method simulates the digestive process in the human gastrointestinal tract via pepsin and pancreatic enzymes (Tavano et al., 2016).

In 1991, the FAO/WHO (Food and Agricultural organization of the United Nations, 1991) suggested using the protein digestibilitycorrected amino acid score (PDCAAS) for evaluating food protein quality. According to the PDCAAS method, the nutritional quality of a food protein is determined by the content of the EAAs and total tract digestibility of crude protein. The amino acid score is calculated by dividing each EAA content by the reference values for 2- to 5-year-old children and adults, respectively. In calculating PDCAAS, the first limiting amino acid score is multiplied by protein digestibility. PDCAAS score of 1 represents that the protein after digestion provides 100 percent of the EAAs required by the organism (World Health Organization, 2007).

Quality protein intake in athletes and physically active individuals is important for their performance. There is limited data about the quality of whey protein supplements available on the market. The aim of this study was to determine the amino acid content and in vitro protein digestibility of whey protein supplements and evaluate their protein quality using in vitro PDCAAS methods.

\section{Materials and methods}

\subsection{Sampling}

In this research, all whey protein supplements (14) were obtained from food supplement market and fitness centers in Istanbul, Turkey.

\subsection{Amino acid analysis}

\section{Protein hydrolysis and derivation}

Protein hydrolysis and the HPLC determination method for amino acids described by Bidlingmeyer et al. (1984) was used with some modifications. First, $0.5 \mathrm{~g}$ sample was added to a $50 \mathrm{~mL}$ schott glass bottle. Then, $20 \mathrm{~mL} 6 \mathrm{~N} \mathrm{HCl}$ solution was added and hydrolyzed in an oven at $120^{\circ} \mathrm{C}$ for $24 \mathrm{~h}$. The hydrolyzed sample was cooled to room temperature and filtered through an ashless filter paper. After that, $0.2 \mathrm{~mL}$ filtrate was moved to a $10 \mathrm{~mL}$ glass test tube and evaporated to dryness at $50{ }^{\circ} \mathrm{C}$ under nitrogen. The sample was washed twice with $0.2 \mathrm{~mL}$ distilled water and 0.2 $\mathrm{mL}$ acetonitrile $(\mathrm{ACN})$ to remove the acid under nitrogen. The derivatization phase of amino acids utilized $0.5 \mathrm{~mL}$ coupling solution (ACN:MeOH:TEA, 100:50:20, v/v) and 0.1 mL Edman's Reagent (1.2\% phenylisothiocyanate in ACN) in a test tube incubated in an oven at $40^{\circ} \mathrm{C}$ for $30 \mathrm{~min}$. The derivatized sample was evaporated to dryness at $40{ }^{\circ} \mathrm{C}$ under nitrogen and then washed two times with $0.2 \mathrm{~mL}$ ACN. After that, $5 \mathrm{~mL} 0.02 \mathrm{M}$ ammonium acetate solution was added and filtered with a $0.45 \mu \mathrm{m}$ cellulose acetate (CA) filter before injecting into the HPLC.

\section{HPLC determination of amino acids}

A Shimadzu Nexera-i HPLC with a Shimadzu UV-20A UVVis detector (Shimadzu Corporation, Kyoto, Japan) was used for separation of amino acids. The mobile phase consisted of buffer solution (A) and ACN (B). Mobile Phase A: $0.78 \mathrm{~g}$ sodium dihydrogen phosphate dehydrate $\left(\mathrm{NaH}_{2} \mathrm{PO} .2 \mathrm{H}_{2} \mathrm{O}\right)$ and $0.88 \mathrm{~g}$ disodium hydrogen phosphate dihydrate $\left(\mathrm{Na}_{2} \mathrm{HPO}_{4} .2 \mathrm{H}_{2} \mathrm{O}\right)$ were weighed into a $1 \mathrm{~L}$ flask and dissolved with deionized water. Then, the $\mathrm{pH}$ of the buffer solution was adjusted to 6.8-6.9 and filtered through a 0.22 $\mu \mathrm{m} \mathrm{CA}$ filter under vacuum. The mobile phase gradient program used in the separation of amino acids is given in Table 1 . The wavelength was $254 \mathrm{~nm}$. The separation was achieved with a Gemini-NX 5u C18 $110 \AA$, 4.6 x $250 \mathrm{~mm}$ column (Phenomenex, CA, USA) with a flow rate of $1 \mathrm{~mL} / \mathrm{min}$. The column oven temperature was $40^{\circ} \mathrm{C}$.

\section{Cysteine analysis}

Cysteine analysis was performed according to the method specified by ISO 13903 (International Organization for Standardization, 2005). First, an oxidation mixture was prepared with $0.5 \mathrm{~mL}$ hydrogen peroxide mixed with $4.5 \mathrm{~mL}$ performic acid-phenol solution $(4.73 \mathrm{~g}$ of phenol in $89 \%$ formic acid and $11 \%$ water). This solution was incubated at room temperature for $1 \mathrm{~h}$ in order to form performic acid. Then, the mixture was cooled in an ice-water bath before adding to the sample. Homogenized sample $(0.5 \mathrm{~g})$ was weighed into a $10 \mathrm{~mL}$ glass test tube with $5 \mathrm{~mL}$ oxidation mixture and refrigerated at $0{ }^{\circ} \mathrm{C}$ for $16 \mathrm{~h}$. After this step, the sample was hydrolyzed, derivatized, and analyzed by HPLC (Section 2.2.1 and 2.2.2.).

\section{Tryptophan analysis}

Tryptophan has an indole structure, which is completely decomposed under acidic conditions; therefore, basic hydrolysis is applied during analysis. The protein hydrolysis and HPLC determination method for tryptophan described by Eroğlu et al. (2016) was used with some modifications. First, $0.5 \mathrm{~g}$ sample was added to a $50 \mathrm{~mL}$ schott glass bottles. Next, $20 \mathrm{~mL} 5 \mathrm{~N} \mathrm{NaOH}$ solution was added and hydrolyzed in oven at $120^{\circ} \mathrm{C}$ for $12 \mathrm{~h}$. The samples were cooled to room temperature and filtered through an ashless filter paper. Next, $1 \mathrm{~mL}$ filtered sample was put into a $250 \mathrm{~mL}$ beaker and adjusted to $\mathrm{pH} 6.3$ using $1 \mathrm{M} \mathrm{HCI}$ solution. Then, the volume was adjusted to $100 \mathrm{~mL}$ with deionized water and filtered through a $0.45 \mu \mathrm{m}$ CA filter before injecting into the HPLC.

\section{HPLC tryptophan determination}

The HPLC system included a Shimadzu Nexera-i device with a RF-20A fluorescence detector (Shimadzu Corporation, Kyoto, Japan). The mobile phase composed of $90 \%$ ammonium acetate $(0.033 \mathrm{M})$ and $10 \% \mathrm{ACN}$. Then, the $\mathrm{pH}$ was adjusted to $6.3 \pm 0.1$ with ortho-phosphoric acid and filtered through a $0.22 \mu \mathrm{m} \mathrm{CA}$ filter under vacuum. The fluorescence detector excitation and emission wavelengths were 280 and $340 \mathrm{~nm}$, respectively. The separation was achieved with a Gemini-NX 5u C18 110 A, 4.6 x $250 \mathrm{~mm}$ column (Phenomenex, CA, USA) with a flow rate of $1 \mathrm{~mL} / \mathrm{min}$. The column oven temperature was $30^{\circ} \mathrm{C}$.

Table 1. HPLC Gradient program for amino acid analysis.

\begin{tabular}{ccc}
\hline Time $(\min )$ & Mobile Phase A (\%) & Mobile Phase B (\%) \\
\hline 0.01 & 100 & 0 \\
13.00 & 84 & 16 \\
22.00 & 64 & 36 \\
26.00 & 60 & 40 \\
26.01 & 40 & 60 \\
33.00 & 100 & 0 \\
40.01 & 100 & 0 \\
\hline
\end{tabular}


In vitro Protein Digestibility (IVPD) and PDCAAS

The in vitro protein digestibility was performed based on method described by Pasini et al. (2001) with some modifications. Samples containing $250 \mathrm{mg}$ protein were weighed in a $50 \mathrm{~mL}$ plastic falcon tube. First, $20 \mathrm{~mL} 0.1 \mathrm{~N} \mathrm{HCI}$ solution was added to the samples and then pepsin enzyme (2800 units/mg, enzyme/ protein ratio of $1: 30(\mathrm{w} / \mathrm{w}))$ was added. The digestion was carried out at $37^{\circ} \mathrm{C}$ for $30 \mathrm{~min}$ in a shaking water bath. After that, $5 \mathrm{~mL}$ phosphate buffer solution $(1 \mathrm{M})$ was added and adjusted to $\mathrm{pH} 7$ with $0.05 \mathrm{NaOH}$ solution. Then, pancreatin (4x U.S.P., enzyme/ protein ratio of $1: 25,(\mathrm{w} / \mathrm{w}))$ solution was added and incubated at $37^{\circ} \mathrm{C}$ for $2 \mathrm{~h}$ in a shaking water bath. After this step, the digestion was stopped by adding $1 \mathrm{~mL} \mathrm{TCA}(20 \%, \mathrm{w} / \mathrm{v})$, the solution was centrifuged at $8000 \mathrm{~g}$ for $5 \mathrm{~min}$, and the pellet was analyzed for nitrogen content using the Kjeldahl method (Association of Official Analytical Chemists, 2012). İn vitro protein digestibility-corrected amino acid scoring (PDCAAS) calculated as follows:

PDCAAS $=((\mathrm{mg}$ of first limiting amino acid in $1 \mathrm{~g}$ test protein $) /$ $(\mathrm{mg} \text { of the same amino acid in } 1 \mathrm{~g} \text { reference protein) })^{*}$ protein digestibility (World Health Organization, 2007).

\subsection{Statistical analysis}

All analyses were performed in triplicate, and the average value was used with standard deviation. Significant differences were assessed using ANOVA Tukey's test $(p<0.05)$.

\section{Results and discussion}

\subsection{Total protein content in whey proteins}

The measured and declared amounts of total protein in whey protein supplements are shown in Table 2. The amount of measured total protein ranged from $54.8 \pm 3.0$ to $74.8 \pm 4.1 \mathrm{~g} / 100 \mathrm{~g}$. The declared amount of protein on the labels ranged between 62 and $86 \mathrm{~g} / 100 \mathrm{~g}$. The measured total protein amount ranged from 75.1 to $117.3 \%$ of the amount listed on the whey protein packaging. The protein content in 6 of 14 samples was less than $10 \%$ of the declared value, whereas in one sample it was more than $10 \%$ of the declared amount. Almeida et al. (2015) compared the amount of protein in whey protein (WP) supplements consumed in the WP-USA and Brazil. The average amount of protein was $83 \%$ in the WP-USA, whereas in WP-Brazil it was $63.36 \%$. In the same study, the quality of whey protein supplements consumed in the WP-USA was higher than in WP-Brazil. When we evaluated our results, total protein content in whey protein supplements consumed in Turkey were higher than $69 \%$. The protein content in whey protein supplements collected in Turkey was between that in the WP-USA and WP-Brazil.

\subsection{Amino acid composition}

The proportions of each amino acid in $100 \mathrm{~g}$ protein from whey supplements are shown in Table 3 . In our study, each amino acid ratio was compared with the results of the study conducted by Pennings et al. (2011). When we compared the proportion of aspartic acid, alanine, tyrosine, BCAAs (valine, isoleucine and leucine), tryptophan and cysteine with the reference, the ratio of these amino acids in all samples were below the reference values. The proportions of glutamic acid ranged between 6.0 and $22.0 \%$. The ratio of glutamic acid was above $10.7 \%$ in 12 out of 14 samples
Table 2. Declared and measured amounts of protein in whey supplements.

\begin{tabular}{cccc}
\hline Sample & Declared $(\mathrm{g} / 100 \mathrm{~g})$ & Measured $(\mathrm{g} / 100 \mathrm{~g})$ & \% of declared \\
\hline 1 & 71 & $64.8 \pm 3.6$ & 91.2 \\
2 & 62.5 & $58.8 \pm 3.2$ & 94.1 \\
3 & 75.8 & $68.8 \pm 3.8$ & 90.7 \\
4 & 78.5 & $70.8 \pm 3.9$ & 90.1 \\
5 & 82 & $71.8 \pm 4.0$ & 87.5 \\
6 & 79.1 & $69.8 \pm 3.9$ & 88.2 \\
7 & 79.1 & $71.8 \pm 4.0$ & 90.7 \\
8 & 73 & $70.8 \pm 3.9$ & 96.9 \\
8 & 62 & $72.8 \pm 4.0$ & 117.3 \\
10 & 79 & $73.8 \pm 4.1$ & 93.4 \\
11 & 86 & $74.8 \pm 4.1$ & 86.9 \\
12 & 73 & $54.8 \pm 3.0$ & 75.1 \\
13 & 80 & $70.8 \pm 3.9$ & 88.5 \\
14 & 76 & $66.8 \pm 3.7$ & 87.9 \\
\hline
\end{tabular}

Values are means \pm standard deviation, $\mathrm{n}=3$. The different letters in the same column indicate statistical differences between samples (ANOVA $\mathrm{p}<0.05$, Tukey's test).

while the ratio was very low in one sample (6.0\%) compared to the reference value (16\%). When we compared the proportion of serine, proline and arginine with the reference values, there were no big differences were found in samples. The ratio of glycine ranged between 1.5 and $4.2 \%$ in 10 out of 14 samples, whereas other samples were very high compared to the reference $(2 \%)$ and ranged between 7.4 and $40.3 \%$. As seen from the results, glycine had the most varied results (Figure 1). As seen from the table, the proportion of histidine in 13 out of 14 samples was less than the reference value (2\%). The proportion of threonine ranged between 1.7 and $9.2 \%$ in 13 out of 14 samples, whereas it was very low in one sample $(0.3 \%)$ compared to the reference value $(4.5 \%)$. When phenylalanine ratios were compared, no big differences were found between samples. However, the ratio of phenylalanine, except in one sample (4.2\%), was below the reference (3.5\%). The ratio of methionine ranged between 0.4 and $2.6 \%$, and lysine between 1.3 and $15.3 \%$ in samples. The ratio of methionine was below the reference value (2\%) in 11 out of 14 samples and lysine was below the reference value (10.5\%) in 10 out of 14 samples.

When we evaluated the amino acid composition in whey protein supplements, the most significant difference was found in the proportions of glycine compared to other amino acids. The ratio of glycine in 4 out of 14 samples ranged between 7.4 and $40.3 \%$. When the amino acid ratios in foods are examined, the largest ratio is in collagen protein. The main content of collagen consists of hydroxyproline, proline, and glycine (Gauza-Włodarczyk et al., 2017). The ratio of glycine in $100 \mathrm{~g}$ protein is 33\% (Paz-Lugo et al., 2018). In another study reported by Van Klinken \& Mook (1990), the ratio of glycine, proline, hydroxyproline, and alanine is 31.7, $11.6,10.1$, and $11.3 \%$, respectively, in $100 \mathrm{~g}$ protein. In our study, the amount of glycine was very high in four samples. This difference may be due to the presence of collagen in the whey protein supplements. However, further studies are needed to confirm this. In addition, the ratios of aspartic acid, alanine, tyrosine, valine, isoleucine, leucine, tryptophan, and cysteine were below the reference values.

The most other significant change was observed in the ratio of cysteine in $100 \mathrm{~g}$ protein. According to the European legislation published in 1990, "Commission Regulation (EEC) No. 2921/90," the value of cysteine in whey protein and casein are $3.0 \%$ and $0.3 \%$, respectively, and these reference values were used for whey protein 


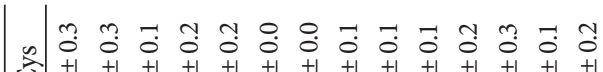

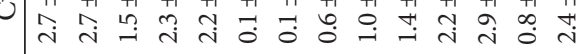
2

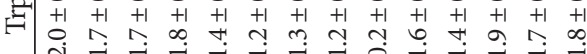
$=0 \mathrm{a}=100$

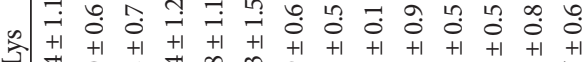

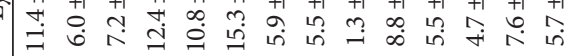

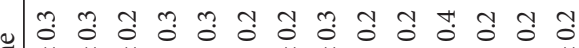

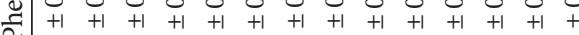

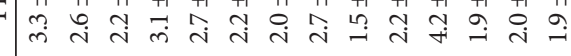
ô 20 ఇ.

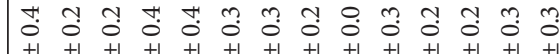

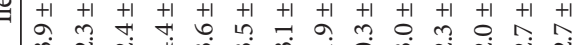
$m$
$y$
4

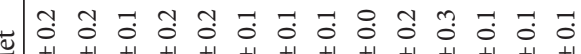

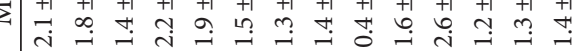

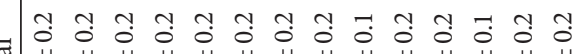

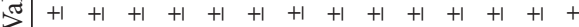

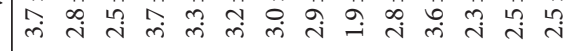

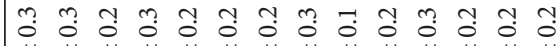

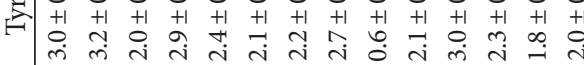

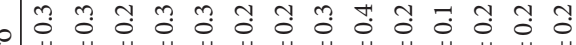

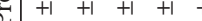

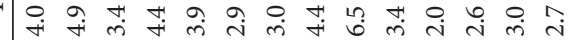
सु

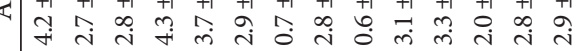

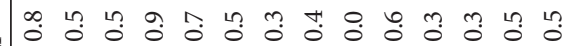

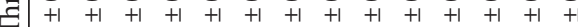
m 서

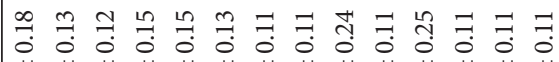
0 +1 $+1+1+1+1+1+1+1+1+1+1+1$ 六 กิ

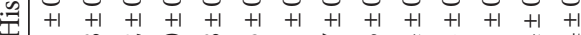

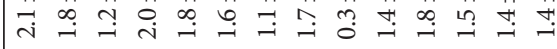

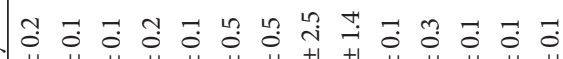

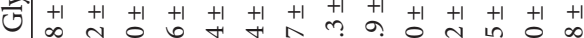
艧

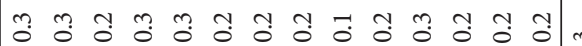

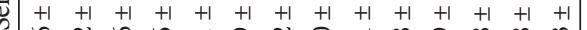
மீ ₹

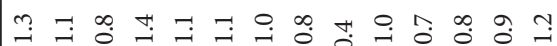

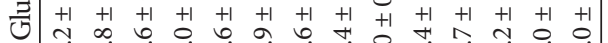

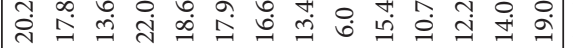

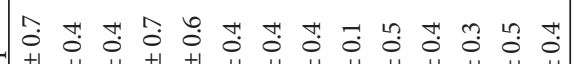

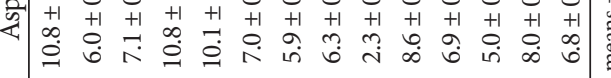




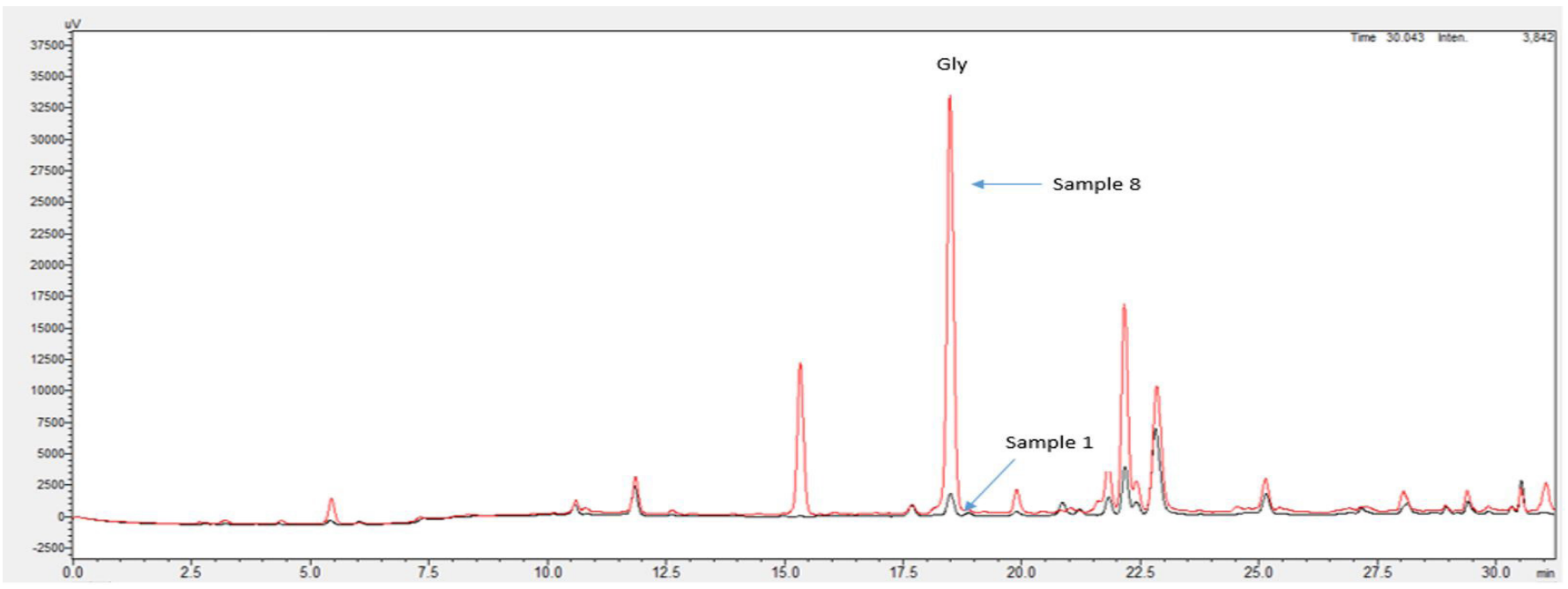

Figure 1. HPLC chromatogram of sample 8 and sample 1.

Table 4. Amount and proportions of essential amino acids (EAA) and branched chain amino acids (BCAA) in whey proteins.

\begin{tabular}{|c|c|c|c|c|}
\hline Sample & EAA $(\mathrm{mg} / 100 \mathrm{~g})$ & BCAA (mg/100 g) & EAA (\%) & $\%$ BCAA \\
\hline 1 & $28447 \pm 1572^{\mathrm{bc}}$ & $10901 \pm 602^{\mathrm{abc}}$ & $44.0 \pm 4.1^{\mathrm{a}}$ & $16.9 \pm 1.6^{\mathrm{ab}}$ \\
\hline 2 & $16972 \pm 938^{e}$ & $6882 \pm 380^{\mathrm{d}}$ & $29.0 \pm 2.7^{\mathrm{cd}}$ & $11.7 \pm 1.1^{\text {cde }}$ \\
\hline 3 & $19537 \pm 1080^{\mathrm{de}}$ & $7456 \pm 412^{\mathrm{d}}$ & $28.5 \pm 2.7^{\mathrm{cd}}$ & $10.9 \pm 1.0^{\mathrm{de}}$ \\
\hline 4 & $32467 \pm 1794^{\mathrm{a}}$ & $12225 \pm 675^{\mathrm{a}}$ & $46.0 \pm 4.3^{\mathrm{a}}$ & $17.3 \pm 1.6^{\mathrm{a}}$ \\
\hline 5 & $27734 \pm 1533^{\mathrm{bc}}$ & $10712 \pm 591^{b c}$ & $38.8 \pm 3.6^{\mathrm{ab}}$ & $15.0 \pm 1.4^{\mathrm{abc}}$ \\
\hline 6 & $29189 \pm 1613^{\mathrm{ab}}$ & $11664 \pm 644^{\mathrm{ab}}$ & $42.0 \pm 3.9^{\mathrm{ab}}$ & $16.8 \pm 1.6^{\mathrm{ab}}$ \\
\hline 7 & $19750 \pm 1091^{\mathrm{de}}$ & $9812 \pm 542^{c}$ & $27.6 \pm 2.6^{\mathrm{cd}}$ & $13.7 \pm 1.3^{\mathrm{bcd}}$ \\
\hline 8 & $17762 \pm 982^{\mathrm{de}}$ & $7129 \pm 394^{\mathrm{d}}$ & $25.2 \pm 2.3^{\mathrm{cd}}$ & $10.1 \pm 0.9^{\mathrm{e}}$ \\
\hline 9 & $5368 \pm 297^{g}$ & $2666 \pm 147^{\mathrm{f}}$ & $7.4 \pm 0.7^{\mathrm{e}}$ & $3.7 \pm 0.3^{\mathrm{f}}$ \\
\hline 10 & $24889 \pm 1376^{c}$ & $10328 \pm 571^{\mathrm{bc}}$ & $33.9 \pm 3.2^{b c}$ & $14.0 \pm 1.3^{\mathrm{abcd}}$ \\
\hline 11 & $20638 \pm 1140^{\mathrm{d}}$ & $7986 \pm 441^{\mathrm{d}}$ & $27.7 \pm 2.6^{\mathrm{cd}}$ & $10.7 \pm 1.0^{\mathrm{de}}$ \\
\hline 12 & $11513 \pm 636^{\mathrm{f}}$ & $4634 \pm 256^{\mathrm{e}}$ & $21.1 \pm 2.0^{\mathrm{d}}$ & $8.5 \pm 0.8^{e}$ \\
\hline 13 & $20588 \pm 1138^{\mathrm{de}}$ & $7773 \pm 430^{\mathrm{d}}$ & $29.2 \pm 2.7^{\mathrm{cd}}$ & $11.0 \pm 1.0^{\mathrm{de}}$ \\
\hline 14 & $17557 \pm 970^{\mathrm{de}}$ & $7246 \pm 400^{\mathrm{d}}$ & $26.4 \pm 2.5^{\mathrm{cd}}$ & $10.9 \pm 1.0^{\mathrm{de}}$ \\
\hline
\end{tabular}

Values are means \pm standard deviation, $\mathrm{n}=3$. The different letters in the same column indicate statistical differences between samples (ANOVA $\mathrm{p}<0.05$, Tukey's test).

quality. The ratio of cysteine in all samples was less than the reference value. In particular, the ratio of cysteine was very low (0.1-1.0\%) in the samples with a high ratio of glycine (7.4-40.3\%). In a recent study conducted by Gauza-Włodarczyk et al. (2017) cysteine was not found in fish skin (FS), collagen, and bovine Achilles tendon (BAT) collagen and was very low in bone collagen ( $0.39 \%)$. In our study, we found very high amounts of glycine in 4 out of 14 samples and a very low amount of cysteine was found compared to reference whey protein. In the literature, collagen contains a high amount of glycine and very low amounts of cysteine. It is thought that these 4 samples may contain some collagen and/or casein. However, further studies are needed to confirm this.

In Table 4, the amount of EAA ranged from 5368 to $32467 \mathrm{mg} / 100$ $\mathrm{g}$ in samples, whereas the proportion ranged from 7.4 to $46.0 \%$. The ratio of EAA is reported as $46.5 \%$ (Pennings et al., 2011) and $46.3 \%$ (Hulmi et al., 2010). When our results were compared to the reference, the ratio was between 38.8 and $46.0 \%$ in 4 out of 14 samples and these results were close to the reference values. In the other 10 samples, the ratio was below $33.9 \%$ compared to the reference value. The amount of BCAA ranged between 2666 and $12225 \mathrm{mg} / 100 \mathrm{~g}$ in samples, while the proportion in $100 \mathrm{~g}$ protein ranged from 3.7 to $17.3 \%$. The reference ratio of BCAA is reported as $28 \%$ (Pennings et al., 2011) and 22.5\% (Hulmi et al., 2010). In our results, the ratio of BCAA in all samples was less than the reference values. EAA and leucine (as BCAA) levels are associated with higher muscle protein synthesis (Luiking et al., 2016). BCAAs are metabolized directly by skeletal muscle. Because BCAAs are digested faster than other amino acids, they can serve as a highly effective source of muscle energy during exercise and as a ready source for muscle protein synthesis after exercise (Nicastro et al., 2012; Shimomura et al., 2004). BCAA and EAA values were very low in our study. According to the results, the use of these products both as a source of fast energy and muscle protein synthesis may be insufficient.

\subsection{Protein Digestibility-Corrected Amino Acid Score (PDCAAS)}

The protein digestibility results of whey proteins are summarized in Table 5 and ranged from 50.4 to $79.6 \%$. Almeida et al. (2015) compared the protein digestibility of whey protein supplements consumed in the WP-USA and WP-Brazil. The in vitro digestibility of whey protein supplements was $91.7 \%$ in a sample collected 


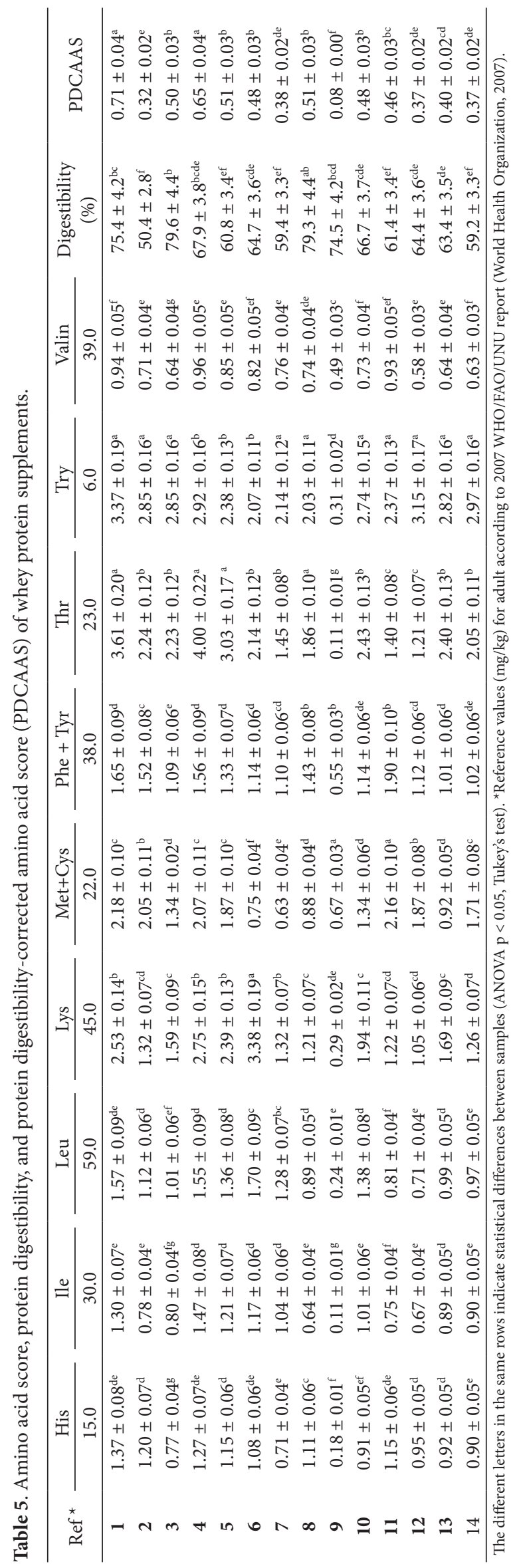


in the WP-USA and $88.4 \%$ in a sample from WP-Brazil. When we evaluated our results, in vitro protein digestibility in whey protein supplements from Turkey were lower than in the USA and Brazil. The low protein digestibility may be attributed to the anti-nutritional factors, complex protein structure, and casein in whey protein supplements.

The PDCAAS values were calculated according to the reference values suggested by the joint $\mathrm{FAO} / \mathrm{WHO} / \mathrm{UNU}$ Expert Consultation (World Health Organization, 2007). The calculated corrected amino acid score and the first limiting amino acid values are presented in Table 5. The first limiting amino acids were isoleucine ( 2 out of 14 samples) or threonine in one of these sample, methionine + cysteine ( 2 out of 14 samples), and valine (10 out of 14 samples) in whey proteins. The lowest calculated corrected amino acid score ranged from 0.11 to 0.96 in samples. When these obtained values were multiplied by IVPD, the PDCAAS ranged from 0.08 to 0.71 .

Almeida et al. (2015) compared the amino acids scores and PDCAAS of whey protein supplements consumed in the WP-USA and WP-Brazil. The amino acid scores of histidine, lysine, and phenylalanine were greater than 1 in whey protein from the WPUSA, whereas in WP-Brazil, the amino acid scores of histidine, lysine, methionine, and phenylalanine were greater than or equal to 1 . In both whey proteins, the amino acid scores of BCAAs were less than 1. BCAAs are an important source of energy in muscle and used for muscle protein synthesis (Nicastro et al., 2012). Due to the low BCAAs scores, athletes or those using these products may not get adequate supplementation. The first limiting amino acids in the WP-USA were isoleucine, methionine, threonine, or valine which have similar scores $(0.6)$, whereas in WP-Brazil, the first limiting amino acid was leucine (score 0.5 ). Thus, the amino acid score of whey protein in the USA was greater than in Brazil. The PDCAAS value of whey protein in the WP-USA was 0.5 and in WP-Brazil was 0.4 , which are low. In our study, we also found low PDCAAS in whey protein collected in Turkey. According to the World Health Organization, PDCAAS expresses the quality of diet protein as well as the ability of diet protein to participate in protein synthesis in the body (World Health Organization, 2007). As can be seen, the PDCAAS values were low in whey protein collected in these countries. Therefore, individuals using these products may not efficiently obtain amino acids as a muscle energy source or for muscle protein synthesis.

\section{Conclusion}

Whey proteins are consumed by both athletes and physically active individuals. Consumption of quality protein intake has a positive effect on both muscle energy sources and muscle protein synthesis. According to the results of our study, high levels of glycine were detected in some samples, whereas very low levels of cysteine were detected, compared to the reference whey protein. Therefore, these results show that there may be collagen or casein present in these products. However, further studies are needed to confirm this. In addition, we found the whey proteins included in this study contain low EAAs and BCAAs. We observed low protein digestibility in all samples. PDCAAs, which is an important parameter in determining dietary protein quality, was generally low in all samples. Based on these results, manufacturers should revise or improve their processing techniques to provide high quality whey protein to consumers.

\section{References}

Almeida, C. C., Monteiro, M. L. G., Costa-Lima, B. R. C., Alvares, T. S., \& Conte-Junior, C. A. (2015). In vitro digestibility of commercial whey protein supplements. Lebensmittel-Wissenschaft + Technologie, 61(1), 7-11. http://dx.doi.org/10.1016/j.lwt.2014.11.038.

Alves, É. D. P., Morioka, L. R. I., \& Suguimoto, H. H. (2019). Comparison of bioethanol and beta-galactosidase production by Kluyveromyces and Saccharomyces strains grown in cheese whey. International Journal of Dairy Technology, 72(3), 409-415. http:// dx.doi.org/10.1111/1471-0307.12588.

Association of Official Analytical Chemists - AOAC. (2012). Official methods of analysis of AOAC (18th ed., Vol. 1, Method 930.29). Gaithersburg: AOAC.

Ballin, N. Z. (2006). Estimation of whey protein in casein coprecipitate and milk powder by high-performance liquid chromatography quantification of cysteine. Journal of Agricultural and Food Chemistry, 54(12), 4131-4135. http://dx.doi.org/10.1021/jf060199k. PMid:16756337.

Bidlingmeyer, B. A., Cohen, S. A., \& Tarvin, T. L. (1984). Rapid analysis of amino acids using pre-column derivatization. Journal of Chromatography B, Biomedical Sciences and Applications, 336(1), 93104. http://dx.doi.org/10.1016/S0378-4347(00)85133-6. PMid:6396315.

Bobe, G., Beitz, D. C., Freeman, A. E., \& Lindberg, G. L. (1998). Sample preparation affects separation of whey proteins by reversed-phase high-performance liquid chromatography. Journal of Agricultural and Food Chemistry, 46(4), 1321-1325. http://dx.doi.org/10.1021/ jf970687f.

Dangin, M., Boirie, Y., Garcia-Rodenas, C., Gachon, P., Fauquant, J., Callier, P., Ballèvre, O., \& Beaufrère, B. (2001). The digestion rate of protein is an independent regulating factor of postprandial protein retention. American Journal of Physiology, Endocrinology and Metabolism, 280(2), E340-E348. http://dx.doi.org/10.1152/ ajpendo.2001.280.2.E340. PMid:11158939.

Eroğlu, N., Akkus, S., Yaman, M., Asci, B., \& Silici, S. (2016). Amino acid and vitamin content of propolis collected by native caucasican honeybees. Journal of Apicultural Science, 60(2), 101-110. http:// dx.doi.org/10.1515/jas-2016-0021.

European Union. (1990, October 11). Commission Regulation (EEC) No. 2921/90 of 10 October 1990 on aid for the production of casein and caseinates from skimmed milk. Official Journal of the European Communities, L279.

Fangmeier, M., Kemerich, G. T., Machado, B. L., Maciel, M. J., \& Souza, C. F. V. D. (2019). Effects of cow, goat, and buffalo milk on the characteristics of cream cheese with whey retention. Food Science and Technology, 39(Suppl. 1), 122-128. http://dx.doi.org/10.1590/ fst.39317.

Food and Agricultural organization of the United Nations - FAO. (1991). Protein quality evaluation (FAO Food and Nutrition Paper, No. 51). Rome: FAO/WHO Expert Consultation.

Gauza-Włodarczyk, M., Kubisz, L., \& Włodarczyk, D. (2017). Amino acid composition in determination of collagen origin and assessment of physical factors effects. International Journal of Biological Macromolecules, 104(Pt A), 987-991. http://dx.doi.org/10.1016/j. ijbiomac.2017.07.013. PMid:28687386.

Guimarães, J. T., Silva, E. K., Alvarenga, V. O., Costa, A. L. R., Cunha, R. L., Sant'Ana, A. S., Freitas, M. Q., Meireles, M. A. A., \& Cruz, A. G. (2018). Physicochemical changes and microbial inactivation after 
high-intensity ultrasound processing of prebiotic whey beverage applying different ultrasonic power levels. Ultrasonics Sonochemistry, 44, 251-260. http://dx.doi.org/10.1016/j.ultsonch.2018.02.012. PMid:29680610.

Guimarães, J. T., Silva, E. K., Ranadheera, C. S., Moraes, J., Raices, R. S., Silva, M. C., Ferreira, M. S., Freitas, M. Q., Meireles, M. A. A., \& Cruz, A. G. (2019). Effect of high-intensity ultrasound on the nutritional profile and volatile compounds of a prebiotic soursop whey beverage. Ultrasonics Sonochemistry, 55, 157-164. http://dx.doi. org/10.1016/j.ultsonch.2019.02.025. PMid:30853535.

Hulmi, J. J., Lockwood, C. M., \& Stout, J. R. (2010). Effect of protein/ essential amino acids and resistance training on skeletal muscle hypertrophy: a case for whey protein. Nutrition \& Metabolism, 7(1), 51. http://dx.doi.org/10.1186/1743-7075-7-51. PMid:20565767.

International Organization for Standardization - ISO. (2005). DS EN ISO 13903: animal feeding stuffs: determination of amino acids content. Geneva: ISO.

Khanam, A., Chikkegowda, R. K., \& Swamylingappa, B. (2013). Functional and nutritional evaluation of supplementary food formulations. Journal of Food Science and Technology, 50(2), 309-316. http://dx.doi. org/10.1007/s13197-011-0344-x. PMid:24425921.

Lucena, M. E., Alvarez, S., Menéndez, C., Riera, F. A., \& Alvarez, R. (2007). a-Lactalbumin precipitation from commercial whey protein concentrates. Separation and Purification Technology, 52(3), 446-453. http://dx.doi.org/10.1016/j.seppur.2006.05.024.

Luiking, Y. C., Abrahamse, E., Ludwig, T., Boirie, Y., \& Verlaan, S. (2016). Protein type and caloric density of protein supplements modulate postprandial amino acid profile through changes in gastrointestinal behaviour: A randomized trial. Clinical Nutrition, 35(1), 48-58. http://dx.doi.org/10.1016/j.clnu.2015.02.013. PMid:25790724.

Nicastro, H., Da Luz, C. R., Chaves, D. F. S., Bechara, L. R. G., Voltarelli, V. A., Rogero, M. M., \& Lancha, A. H. Jr (2012). Does branched-chain amino acids supplementation modulate skeletal muscle remodeling through inflammation modulation? Possible mechanisms of action. Journal of Nutrition and Metabolism, 2012, 136937. http://dx.doi. org/10.1155/2012/136937. PMid:22536489.

Norton, L. E., \& Layman, D. K. (2006). Leucine regulates translation initiation of protein synthesis in skeletal muscle after exercise. The Journal of Nutrition, 136(2), 533S-537S. http://dx.doi.org/10.1093/ jn/136.2.533S. PMid:16424142.

Pasini, G., Simonato, B., Giannattasio, M., Peruffo, A. D., \& Curioni, A. (2001). Modifications of wheat flour proteins during in vitro digestion of bread dough, crumb, and crust: an electrophoretic and immunological study. Journal of Agricultural and Food Chemistry, 49(5), 2254-2261. http://dx.doi.org/10.1021/jf0014260. PMid:11368585.

Paz-Lugo, P., Lupiáñez, J. A., \& Meléndez-Hevia, E. (2018). High glycine concentration increases collagen synthesis by articular chondrocytes in vitro: acute glycine deficiency could be an important cause of osteoarthritis. Amino Acids, 50(10), 1357-1365. http://dx.doi. org/10.1007/s00726-018-2611-x. PMid:30006659.

Pennings, B., Boirie, Y., Senden, J. M., Gijsen, A. P., Kuipers, H., \& van Loon, L. J. (2011). Whey protein stimulates postprandial muscle protein accretion more effectively than do casein and casein hydrolysate in older men. The American Journal of Clinical Nutrition, 93(5), 9971005. http://dx.doi.org/10.3945/ajcn.110.008102. PMid:21367943.

Pouliot, Y., Wijers, M. C., Gauthier, S. F., \& Nadeau, L. (1999). Fractionation of whey protein hydrolysates using charged UF/NF membranes. Journal of Membrane Science, 158(1-2), 105-114. http:// dx.doi.org/10.1016/S0376-7388(99)00006-X.

Rankin, D., \& Darragh, A. (2006). Dietary protein in an endurance exercise recovery beverage: what is the value of whey. In Proceedings of the 4th International Whey Conference (pp. 36-46). Chicago: American Dairy Products Institute.

Sava, N., Van der Plancken, I., Claeys, W., \& Hendrickx, M. (2005). The kinetics of heat-induced structural changes of $\beta$-lactoglobulin. Journal of Dairy Science, 88(5), 1646-1653. http://dx.doi.org/10.3168/ jds.S0022-0302(05)72836-8. PMid:15829655.

Shimomura, Y., Murakami, T., Nakai, N., Nagasaki, M., \& Harris, R. A. (2004). Exercise promotes BCAA catabolism: effects of BCAA supplementation on skeletal muscle during exercise. The Journal of Nutrition, 134(6, Suppl.), 1583-1587. http://dx.doi.org/10.1093/ jn/134.6.1583S. PMid:15173434.

Tang, J. E., Moore, D. R., Kujbida, G. W., Tarnopolsky, M. A., \& Phillips, S. M. (2009). Ingestion of whey hydrolysate, casein, or soy protein isolate: effects on mixed muscle protein synthesis at rest and following resistance exercise in young men. Journal of Applied Physiology, 107(3), 987-992. http://dx.doi.org/10.1152/japplphysiol.00076.2009. PMid:19589961.

Tavano, O. L., Neves, V. A., \& Silva, S. I. Jr. (2016). In vitro versus in vivo protein digestibility techniques for calculating PDCAAS (protein digestibility-corrected amino acid score) applied to chickpea fractions. Food Research International, 89(Pt 1), 756-763. http:// dx.doi.org/10.1016/j.foodres.2016.10.005. PMid:28460976.

Tipton, K. D., Elliott, T. A., Cree, M. G., Wolf, S. E., Sanford, A. P., \& Wolfe, R. R. (2004). Ingestion of casein and whey proteins result in muscle anabolism after resistance exercise. Medicine and Science in Sports and Exercise, 36(12), 2073-2081. http://dx.doi.org/10.1249/01. MSS.0000147582.99810.C5. PMid:15570142.

Trindade, M. B., Soares, B. C. V., Scudino, H., Guimarães, J. T., Esmerino, E. A., Freitas, M. Q., Pimentel, T. C., Silva, M. C., Souza, S. L. Q., Almada, R. B., \& Cruz, A. G. (2019). Cheese whey exploitation in Brazil: a questionnaire survey. Food Science and Technology, 39(3), 788-791. http://dx.doi.org/10.1590/fst.07419.

Van Klinken, G. J., \& Mook, W. G. (1990). Preparative high-performance liquid chromatographic separation of individual amino acids derived from fossil bone collagen. Radiocarbon, 32(2), 155-164. http://dx.doi. org/10.1017/S0033822200040157.

Williams, M. (2005). Dietary supplements and sports performance: amino acids. Journal of the International Society of Sports Nutrition, 2(2), 63-67. http://dx.doi.org/10.1186/1550-2783-2-2-63. PMid:18500957.

World Health Organization - WHO. (2007). Protein and amino acid requirements in human nutrition: report of a joint FAO/WHO/ UNU expert consultation (WHO Technical Report Series, No. 935). Geneva: WHO. 